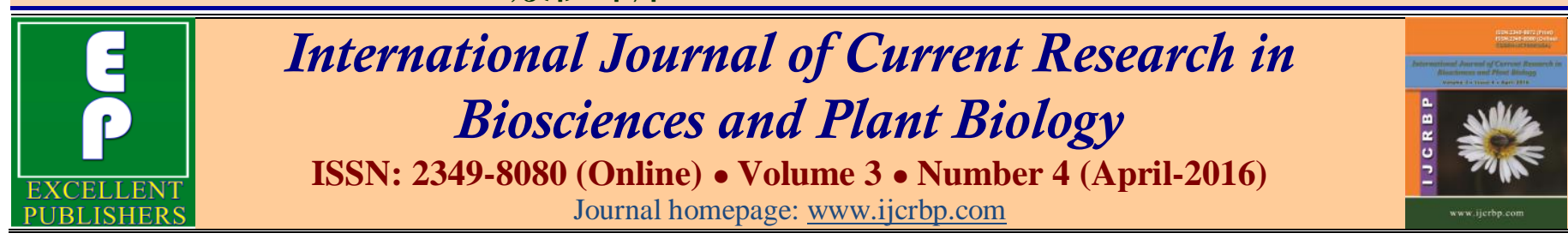

Review Article

doi: http://dx.doi.org/10.20546/ijcrbp.2016.304.011

\title{
Sacred Groves of India - An Overview
}

\author{
M. Amirthalingam* \\ C.P.R. Environmental Education Centre, No. 1, Eldams Road, Alwarpet, Chennai-6oo o18, Tamil Nadu, India
}

*Corresponding author.

\section{Abstract}

Sacred groves can be defined as undisturbed patches of vegetation on the outskirts of villages and towns or in the plains or a part of forested areas that are dedicated to local folk deities or ancestral spirits. They are fine examples of in-situ conservation. They vary in size between $05-500$ hectares. Their existence depends upon the social traditions and taboos incorporating spiritual and ecological values which prevent their destruction. These groves represent an invaluable gene pool, conserve the biodiversity and are found all over the country under different names. Sacred groves provide various ecosystem services such as biodiversity, medicinal plants; regulating services and the range of functions carried out by ecosystems. It also serves as a repository for biodiversity. These pristine patches of forests have been instrumental in saving many vanishing species that might otherwise have been destroyed. The entire ecosystem helps in soil and water conservation, apart from preserving biological wealth. They are a dependable source of water for organisms living in and around the sacred groves. Hunting, logging and other developmental activities are strictly prohibited within the sacred groves. Besides, the sacred groves serve to maintain the precious age old religious and cultural practices, beliefs and customs that might otherwise have been lost in this era of globalization and mass culture. Thus, sacred groves provide some very important ecological services to mankind.
\end{abstract}

\section{Article Info}

Accepted: 27 March 2016

Available Online: 06 April 2016

\section{Keywords}

Beliefs and customs

Biodiversity

Ecosystem services

In-situ conservations

Sacred groves

Spiritual values

\section{Introduction}

India has an ancient tradition of conserving nature that goes right back to the pre-Vedic age. This tradition probably can be traced further back in time to foodgathering societies, who venerated nature and the natural resources on which they depended for their existence. Our rich literary heritage consisting of the Puranas and the Epics have celebrated the varied flora and fauna of the sub-continent, its magnificent forests, rivers, mountains and various other manifestations of nature with which the sub-continent is blessed. Vedic literature is replete with vivid descriptions of the grandeur and beauty of India's forests. As is well known, the ancient rishis used to make their homes or ashrams in the midst of thick forests of sylvan beauty. The Aranyakas are named after the forests which provided their authors with a home and inspiration. A good part of the Epic Ramayana is set in the Dandakaranya forest which was known for its scenic splendour. These have been beautifully chronicled by the great poets like Kamban and Kalidasa. The Pandavas, too, spent a good part of the period of their exile in the forests which has been vividly described in the Mahabharata. Our ancestors were aware of the symbiotic relationship between the bio-physical ecosystem and socio-economic institutions and the strong cultural relations that bind them. Thus, in our ancient tradition, culture and environment have always been regarded as complimentary to each other. 
It is believed that the sacred groves originated after the introduction of the practice of agriculture and are found in almost all parts of India. They can be described as a mini-ecosystem containing a rich repository of nature's unique biodiversity. They are also a product of the socio-ecological philosophy of our ancestors. The ancient religious beliefs and traditions which have been handed down through thousands of generations have played a unique role in the preservation of these miniecosystems.

Many sacred groves constitute pristine vegetation and are rich in vegetation and associate groups of organisms. A few species found in the sacred groves are also important keystone species, which maintain the biodiversity of the grove. In many cases, they represent the remnant nearnatural vegetation. They also serve as a seed source through dispersal by birds. They are also an important refuge for rare and endangered medicinal plants (Joshi and Gadgil, 1991). In addition, transpiration from the sacred groves increases atmospheric humidity and reduces temperature in the immediate vicinity and produces a favourable microclimate for several organisms. Sacred groves thus play a crucial role in soil conservation. Soil erosion is prevented because of water retention capacity and the soil binding nature of trees. The root mat prevents the nutrients from leaching out. They also play an important role in soil and water conservation and are often the only source of water for many animals and birds. They also protect the watersheds and water sources. In short, sacred groves provide some very important ecological services to mankind.

The sacred groves vary immensely in size. Some contain only a few trees while others are hundreds of acres in size. Some form part of large forested areas while others exist as islands in open plains or deserts. The sacred groves are closely linked to the local communities and various endogamous groups. For example, in India alone the groves are associated with almost 40,000 endogamous groups within the Hindu caste system. In any case, the preservation of these groves has been found to be strongly linked to caste and religious grouping supported by traditional religious and social beliefs. This has helped to preserve them in a relatively undisturbed state. They also help to define the cultural identity of the communities that protect them. They are also closely linked with the politics and economies of these communities. In the majority of the cases, the management of these groves is a associated with separate caste groups, by a village as a whole or by a clan. In India, the sacred groves are still in the process of being documented. There are 13,270 sacred groves that are found to be intact. Out of this only 138 hectares comprise of totally undisturbed vegetation and about 3188 hectares have an open canopy. However, initial studies indicate that the number of sacred groves in the country may be as high as 100,000 to 150,000 (Malhotra, 1998). The total area under sacred groves in India has been estimated to be 33,000 hectares which comes to 0.01 percent of the total area of the country. However, the actual area could be as high as 42,000 hectares taking into account the 4,415 sacred groves reported so far (Gokhale et al., 1998). However, in contrast to the above facts, C.P.R. Environmental Education Centre has so far documented a total of 10,377 sacred groves which have been authenticated. The breakup of the groves state wise is given in Table 1 and Fig. 1.

\section{Types of sacred groves}

Sacred groves may be classified into five categories as mentioned below:

- Local village sacred groves, which are managed by the entire village, although the village may be composed of several tribal communities and ethnic groups.

- Regional sacred groves, which are managed by a temple trust, and which are visited by people from several districts (e.g. Sabarimala sacred grove at Kanjikkuzhi, Alappuzha district Kerala).

- Pan-Indian sacred groves, which are large and are managed by a temple trust, where people from many parts of the country visit and worship the deity, (e.g. Garhwal Himalayas).

- Sacred groves as the abode of ancestral spirits, which are both a burial ground and location of deity and ancestor worship

\section{Sacred groves and their status in different states of India}

The sacred groves are known by different nomenclature in various parts of the country. According to Malhotra (1998), around 13,270 groves have been reported from all over the country. Some of the important areas where the survey is being conducted like Chhattisgarh, Kerala, Madhya Pradesh, Odisha, Rajasthan, Bihar, Mizoram, Nagaland and Himachal Pradesh are yet to report the true picture of the sacred groves. 
Table 1. State-wise breakup of sacred groves (SG) in India.

\begin{tabular}{|c|c|c|c|c|}
\hline S. No. & Location & No. of SG & Districts & Source \\
\hline 1. & Andhra Pradesh & 677 & 13 & WWF, Andhra Pradesh (1996) \\
\hline 2. & Arunachal Pradesh & 58 & 2 & Chatterjee et al. (2000) \\
\hline 3. & Arunachal Pradesh & 101 & 4 & Khan (2007) \\
\hline 4. & Assam & 17 & & Karbi Anglong Community Resource Management Society \\
\hline 5. & Assam & 12 & 1 & Pramod Medhi and Sachin Kumar Borthakur (2013) \\
\hline 6. & Bihar & 43 & 2 & Ranwa et al. (1998) and Gokhale (2002) \\
\hline 7. & Chhattisgarh & 6 & 2 & Patnaik and Pandey (2014) \\
\hline 8. & Chhattisgarh & 57 & - & Rahangdale et al. (2014) \\
\hline 9. & Goa & 93 & - & Rajendra Kerkar (2010) \\
\hline 10. & Gujarat & 6 & 1 & Patel and Patel (2012) \\
\hline 11. & Gujarat & 4 & 1 & Maru and Patel (2013) \\
\hline 12. & Gujarat & 5 & 1 & Patel and Patel (2013) \\
\hline 13. & Gujarat & 6 & 1 & Patel Hitesh and Patel (2013) \\
\hline 14. & Gujarat & 18 & 1 & Community conserved areas, (Gujarat), Kalpavriksh, Pune (2004). \\
\hline 15. & Gujarat & 1 & 1 & Nimisha et al. (2013) \\
\hline 16. & Gujarat & 2 & 1 & Patel et al. (2014) \\
\hline 17. & Jammu and Kashmir & 16 & - & Gupta and Sharma (2013) \\
\hline 18. & Jammu and Kashmir & 60 & - & Priya and Sharma (2014) \\
\hline 19. & Jammu and Kashmir & 16 & - & Sharma and Devi (2014) \\
\hline 20. & Jharkhand & 29 & 1 & Mahato (2012) \\
\hline 21. & Karnataka & 1476 & - & Chandran and Gadgil (1998) \\
\hline 22. & Kerala & 644 & & Induchoodan, 1996 \\
\hline 23. & Kerala & 452 & 13 & http://www.forest.kerala.gov.in/ \\
\hline 24. & Haryana & 248 & - & NAEB (1995) \\
\hline 25. & Himachal Pradesh & 329 & - & Sacred Groves of Himachal Pradesh, Down to Earth, 31 December, 2003 \\
\hline 26. & Madhya Pradesh & 23 & - & Kala (2011) \\
\hline 27. & Madhya Pradesh & 77 & - & Shrivastava et al. (2011) \\
\hline 28. & Madhya Pradesh & 49 & - & Masih and Homkar (2009) \\
\hline 29. & Madhya Pradesh & 20 & 10 & Rajiv Rai (2014) \\
\hline 30. & Maharashtra & 1600 & - & Deshmukh et al. (1998) \\
\hline 31. & Maharashtra & 250 & 1 & Godbole et al., 1998 \\
\hline 32. & Maharashtra & 483 & 10 & Gadgil and Vartak (1981b) \\
\hline 33. & Manipur & 166 & 4 & Khumbongmayum, et al. (2004) \\
\hline 34. & Manipur & 365 & - & Devi (2000) \\
\hline 35. & Meghalaya & 105 & 6 & Tiwari et al. (1999) \\
\hline 36. & Odisha & 169 & - & Malhotra et al. (1998) \\
\hline 37. & Odisha & 6 & - & Debabrata et al. (2014) \\
\hline 38. & Odisha & 13 & - & Mohanta and Adhikari (2012) \\
\hline 39. & Puducherry & 108 & - & $\begin{array}{l}\text { Dr. V.Krishnan, Plant Biodiversity, Bio-cultural Perspectives of Sacred } \\
\text { Groves of Pondicherry and its environs }\end{array}$ \\
\hline 40. & Rajasthan & 570 & 13 & Aman Singh, Krishi Avam Paristhitiki Vikas Sansthan (KRAPAVIS) \\
\hline 41. & Sikkim & 16 & - & $\begin{array}{l}\text { ENVIS Newsletter, The Forest, Environment \& Wildlife Managemnt, } \\
\text { Government of Sikkim (2011) }\end{array}$ \\
\hline 42. & Tamil Nadu & 1275 & 31 & Amirthalingam (2012) \\
\hline 43. & Telangana & 57 & 10 & WWF, Andhra Pradesh (1996) \\
\hline 44. & Uttarakhand & 4 & 1 & Dhaila-Adhikari and Adhikari (2007) \\
\hline 45. & Uttarakhand & 16 & 1 & $\begin{array}{l}\text { Dr. S.S. Samant, Govind Ballabh Pant Institute of Himalayan } \\
\text { Environment and Development, GBPIHED, Almora }\end{array}$ \\
\hline 47. & Uttarakhand & 3 & 1 & CCA (ed.) Neema Pathak, Kalpavriksh (2009) \\
\hline 48. & Uttarakhand & 102 & - & Gokhala and Pala (2011) \\
\hline 49. & Uttarakhand & 7 & - & Sing et al. (2014) \\
\hline 50. & Uttar Pradesh & 32 & - & Singh $(2011)$ \\
\hline 51. & West Bengal & 46 & - & Ranwa et al. (2002) \\
\hline 52. & West Bengal & 20 & - & Pandit and Bhakat (2006) \\
\hline 53. & West Bengal & 3 & - & Bhakat and Sen (2008) \\
\hline 54. & West Bengal & 57 & - & Dandapat and Mishra (2014) \\
\hline 55. & West Bengal & 190 & - & Deb and Malhotra (2001) \\
\hline 56. & West Bengal & 670 & 5 & Deb et al. (1997) \\
\hline
\end{tabular}


A matter of serious concern is the steady erosion of traditional and cultural values among the local communities, which in turn, has adversely affected the preservation of these groves. It has already been seen that the traditional beliefs and taboos have played a vital role in maintaining these islands of biodiversity. However, the impact of modernization and education and growing disbelief in the traditional value systems among the local communities has impacted the preservation of the groves. Pressures of growing urbanization and industrialization, the need for roads and housing and other infrastructure has eaten into the area of the groves. However, a heartening feature is that the environmentally conscious communities and civil societies have taken up this cause in right earnest and the trend is being reversed.

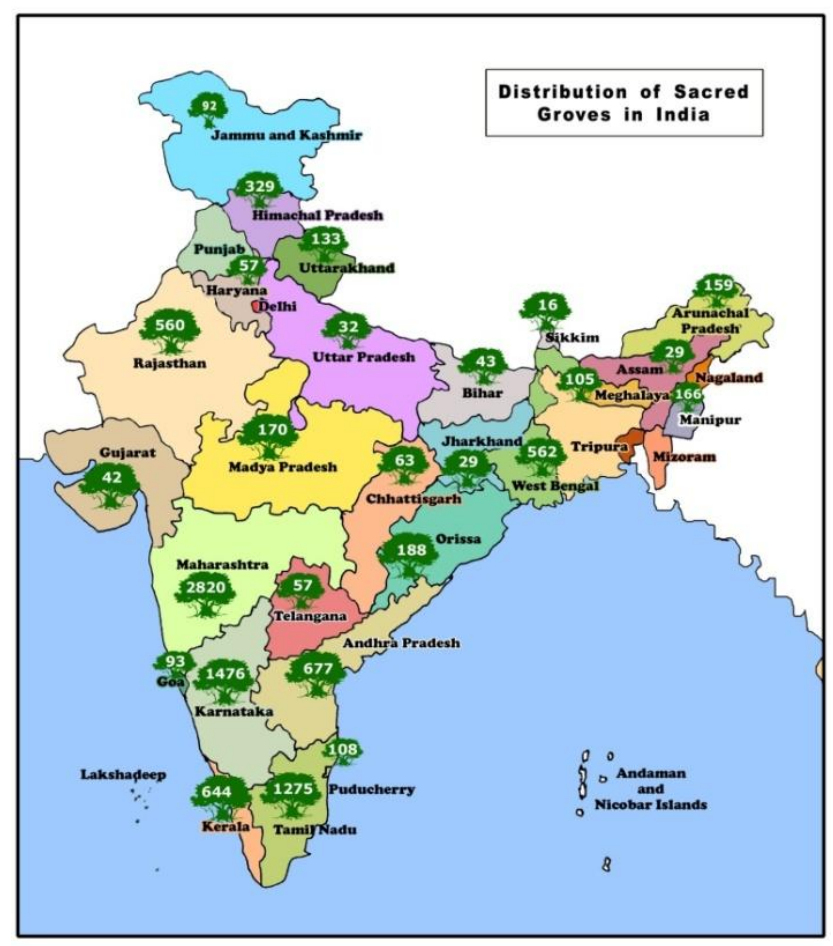

Fig. 1: Distribution of sacred groves in India (Source: cpreecenvis.nic.in).

\section{Andhra Pradesh}

The sacred groves in Andhra Pradesh are known as Pavithravanams. A total number of 730 sacred groves have been documented till date. These Pavithravanas or sacred groves are dedicated to various local deities and also to Hindu gods and goddesses. Some of the deities to whom the sacred groves are dedicated are Shiva, Rudrakoteswara, Hanuman, Saraswathi, Thimmaraya swamy, Gangamma, Nagadevatha and Akkamma (WWF Andhra Pradesh, 1996).
Sacred groves in Andhra Pradesh are deteriorating at an alarming rate due to changes in religious beliefs and developmental pressures. Many temples associated with sacred groves have been modernised by removing the vegetation. Some of the species commonly found in the sacred groves of Andhra Pradesh are black plum, tamarind, mango, jackfruit, neem, beechwood and pipal. Some of the species have unique abilities such as nitrogen fixation etc. Such species are variously known as keystone species or functional groups.

\section{Arunachal Pradesh}

In Arunachal Pradesh, a few of the sacred groves managed by Lamas and the Mompa tribe, are attached to the Buddhist monasteries and they are called Gompa Forest Areas (GFAs). A total of 65 sacred groves have been documented so far. These sacred groves are dedicated to local deities such as Ubro or Ubram and Thouw-gew. Various ethnic groups of northeastern India have preserved and protected several forest patches and even individual trees or animals due to their traditional beliefs and respect for nature. These monasteries with sacred groves are mainly located in West Kameng and Tawang districts of the State; 58 GFAs were reported from these two districts and a few sacred groves from Lower Subansiri and Siang district of the state. Some of the species commonly found in the sacred groves of Arunachal Pradesh are banyan, pipal, ashoka, bela and harada (Khan et al., 2007).

\section{Assam}

Forest dwelling tribes such as Bodo and Rabha inhabiting the plains and foothills of Western Assam have the tradition of maintaining sacred groves which are locally called "Than". Dimasa tribes of the North Cachar hills in Haflong district of Assam call the sacred groves "Madaico". A total of 40 sacred groves have been documented so far. Shankara Deva, Sibrai, Alu Raja, Naikhu Raja, Wa Raja, Ganiyang- Braiyung and Hamiadao are the various deities to whom these sacred groves are dedicated. Vaishnav temples like "Shankara Deva Mathas" distributed all over the state of Assam also have sacred groves.

Giant bamboo, pear bamboo, pink banana, metico pepper, Indian smilax, Areca nut, sand paper tree and Devil's cotton are some of the commonly found species. The identity of an area/village is often associated with plant resource either available in the area/village or importance to the people. There is a taboo on the groves 
on the killing of deer during the mating season and protection is extended to birds during the nesting period (Medhi and Borthakur, 2013).

\section{Bihar}

Although, there are several tribes among whom this tradition is present in Bihar, not much information is available about sacred groves in the State. The sacred groves in Bihar are locally known as Sarnas. A total of 43 sacred groves have been documented so far. Raksel, Darha, Marang-Baru, Jaher-Buri, Chandi, Dharti, Satbahini and Jaherera are some of the deities to whom these groves are dedicated (Mitra and Pal, 1994). Bamboos and sal trees are the most commonly found species in the sacred groves. Hatubongako or the village gods occupy the most significant place in the groves and they are regarded as the guardians of the village and their help is invoked in agricultural and other economic operations (Mishra, 2005).

\section{Chhattisgarh}

In Chhattisgarh, the sacred groves are locally known as Matagudi, Devgudi and Gaondevi. A total of 600 sacred groves have been found in the Chhotanagpur region of the State. Some of the species commonly found in the sacred groves are sal, Indian gooseberry, bedda nut, Indian laurel, Indian frankincense tree, black myrobalan, Cuddapah almond, Indian butter tree and Axile wood. Most of the groves are managed by the local community (ies) and owned by a group of families, or a clan. The community rituals are often synchronized with the blossoming of flowers of forest trees and different agricultural operations. These rituals reveal the close sense of harmony that exists between nature and tribal communities (Patnaik and Pandey, 1998).

\section{Goa}

In Goa, sacred groves are known by various names such as Devrai, Devran or Pann. The best preserved sacred groves of Goa are situated in Keri village of Sattari. A total of 93 sacred groves have been documented so far. Durgah and Rashtroli are the deities to which the sacred groves are dedicated in Goa. Some of the species commonly found in the sacred groves are Ceylon oak, red silk cotton tree and pipal tree. The tribals of GoaGavda, Kunbi, Velip and Dhangar-gouli worship various forms of nature. They have a tradition of sacred cow, sacred goat, sacred banyan tree, sacred hill, sacred stone, sacred ponds and also sacred groves (Kerkar, 2010).

\section{Gujarat}

Sacred groves are seen throughout Gujarat, having varied forms, cultural practices and belief systems. They are locally known as sacred groves and are called Oran Mata and Sadhay Pir. A total of 42 sacred groves have been documented so far (Patel, and Patel, 2012). Khodiyar mata, Oran Mata, Jhalai mata, Panch Krishna, Mahadev are some of the deities to whom these sacred groves are dedicated. The vegetation in the groves is highly varied viz. mangroves, fresh water swamps, or other tropical forest types. Cotton tree, Bengal quince, neem, mango, flame of the forest, sissoo, thorny staff tree, banyan and pipal are some of the most commonly found species in these groves. Sacred groves thus play an important role in the conservation of biodiversity, recharge of aquifers and soil conservation. It is strictly prohibited to cut or climb the trees and remove dead wood (Patel, 2004).

\section{Haryana}

In Haryana, unlike in many other states, there is no generic name for sacred groves although the sites are protected for similar reasons. There is a lack of data regarding the number of sacred groves. Khetanath, Jairamdas, Shiv, Bala Sundari, Nao Gaja and Mani Goga Peer are the some of the deities to whom these sacred groves are dedicated. The common species found in these sacred groves are white pear, Mandarin, Bruisewort, garden violet, lac tree, elm, pipal, banyan and flame of the forest. The groves act as a repository for medicine and as a source of honey, fruits and water (Yadav et al., 2010).

\section{Himachal Pradesh}

In Himachal Pradesh, the local myths and legends associated with sacred groves go a long way in preserving the forests from destruction. There are several groves dedicated to a particular deity called Dev Van or Devta Ka Jungle where one is not allowed to cut trees or even carry dry leaves outside the area. Bakhu Nag Devta, Ringarishi Devta (embodiment of an ancient sage) and Devi, are the deities to whom these sacred groves are dedicated. The common species found in these sacred groves are deodar, kail and oak with occasional spruce and silver fir. The thick forests provide a good habitat for leopards, barking deers, ghorals, black bears, hares, wolves and many more animals. There are about 10,000 temples in the state with well defined management committees and biradari panchayats (caste councils) and all the major deities in the state have their own groves. 
Hence, the state can be called as the 'land of deities and sacred groves' (Quarterly ENVIS Newsletter, Volume A2, Oct.-Dec., 2006).

\section{Jammu and Kashmir}

Sacred groves are present all over Jammu and Kashmir, managed by religious bodies or management committees. The local names of the groves are known as Banis. A total of 76 sacred groves have been documented so far. Baba Roachi Ram, Bua Sjawati ji, Bua Dati ji, Lord Hanuman, Mata Vaishno Devi, Peer Baba and Raja Mandlik ji are some of the deities to whom these groves are dedicated. Some of the species commonly found in the sacred groves are mango, banyan, indian plum, mountain ebony, pipal, three-leaved caper, white fig, bengal quince and neem. The Shankaracharya sacred grove is a reserve forest being maintained for aesthetic and recreational purposes. In larger groves, normal forestry operations are carried out and the income goes to the shrine. Small groves are highly protected and to remove anything from the grove is a taboo. People living around the groves voluntarily protect them (Sharma and Devi, 2014).

\section{Jharkhand}

The tribals of Jharkhand worship their sacred groves known as sarnas. A total of 29 sacred groves have been documented so far. A sarna is a cluster of trees where the adivasis would worship in various occasions. Such a grove (among many others) must have at least five saal (Shorea robusta) trees (also known as sorjum), held very sacred by the tribals. Non-tribal Hindus also worship in such sarnas in many villages of Jharkhand. They call them mandar. Some of the species commonly found in the sacred groves are Indian black plum, Indian plum, white marudah, tulasi, indian gooseberry, neem, mango, Malabar nut, thorn apple, sal and champak. The sarhul festival is celebrated in the sarhul sarana. The festival is celebrated when the sal trees start flowering (Mahato, 2014).

\section{Karnataka}

The most notable community conserved areas of Karnataka are its sacred groves. They vary in terms of size, ownership patterns and also with respect to the vegetation. The groves in the state broadly come under two classes: Smaller groves or Kans (These are entirely protected) and Larger groves or Devarkadu/Devarkan (These groves also function as a resource forest, offering both sustenance and ecological security) (Chandran and Ramachandran, 2014). A total of 1476 sacred groves have been documented in Karnataka. Jatakappa, Bhutappa and Choudamma, Mailara, Bhairava and Govardhan are some of the deities to whom these groves are dedicated. The following species are commonly found in the sacred groves of Karnataka - Crab's eye, Sage leaved alangium, neem, pipal, pithraj tree and powder-puff. These sacred groves are rich in biodiversity due to the unique management and ownership of the sacred groves. A unique feature is the offering of terracotta icons of hounds in the groves of Kodagu (Kushalappa, 2014).

\section{Kerala}

The sacred groves in Kerala are locally known as Ayyappan kavu or Sastham kavu, Bhagavathi kavu or Amman kavu, Vanadevatha and Cheema or Cheerumba depending upon the ownership and the deities to whom these groves are dedicated. A total of 644 sacred groves have been documented so far in Kerala. Sastha, Bhagavathi, Sarpa kavu, Amman, Kamaljai, Mariai, Bhavani, Bhagvati and Tathawade are the deities to whom these groves are dedicated. The following species are commonly found in the sacred groves - White dammar, Night-flowering jasmine, black varnish tree, Niepa bark tree, Santa Maria tree, Ceylon Ironwood and Tamarind etc. Serpent worship is an important feature of the sacred groves in the State. A new species of a leguminous climber Kunstleria keralensis, has been reported from one of the sacred groves of Kerala (Induchoodan, 1996).

\section{Madhya Pradesh}

Madhya Pradesh is one of the tribal dominated states in Central India (19.9\%). A large number of plants are conserved in the sacred groves commonly known as Deogudi /Sarnas. In Madhya Pradesh there are about 101 sacred groves. Bursung, Pat Khanda, Ganganamma, Mahadev, Bhandarin mata and Danteshwari mata are some of the deities to whom these groves are dedicated. The following species are commonly found in the sacred groves -Indian butter tree, banyan, peepal, calotrop, indian mesquite, bengal quince, flame of the forest, khakan and sal tree. The tribals believe that if the plants are not maintained properly or are destroyed, natural calamity will ruin their clan (Rajiv Rai, 2014).

\section{Maharashtra}

In Maharashtra, sacred groves are found in tribal as well as non-tribal areas. The sacred groves in the western part 
are called Devrai or Devrahati, whereas in the eastern part the Madiya tribals call it Devgudi. A total of 2820 sacred groves have been documented in Maharashtra (Deshmukh, 1999). Maruti; Vaghoba, Vira, Bhiroba, Khandoba and Shirkai are some of the deities to whom these groves are dedicated. The following species are commonly found in the sacred groves of Maharashtra - portia tree, casuarina, silk cotton tree, indian laurel, indian elm, bead tree, Indian butter tree, turmeric and Japanese ginger. The felling of timber and the killing of animals in the sacred groves is taboo. Sacred groves form an important landscape feature in the deforested hill ranges of the Western Ghats of Maharashtra (Ghate, 2014).

\section{Manipur}

The worshipping and protection of forests called "Umanglai" because of their associated deities are still practiced by the modern Manipuris preserving the ancient tradition till date. These groves are locally known as Gamkhap and Mauhak (sacred bamboo reserves). A total number of 166 sacred groves have been recorded in Manipur. Umanglai, Ebudhou Pakhangba, Konthoujam Lairembi, Chabugbam and Chothe Thayai Pakhangba are some of the deities to whom these groves are dedicated. There are also forest belts that are protected as sacred around the habitations called as Gamkhap. Gangte tribals are also having small reserves of bamboo called mauhak. Extraction of bamboo shoots from mauhak is totally prohibited.

Ecologically valuable species like siris and cluster fig, which conserve high amounts of nitrogen, phosphorous, magnesium and calcium in their leaves are found in several sacred groves of Manipur. Keystone species contribute to the maintenance of biodiversity and culture. There are about 16 sacred species found in different sacred groves of Manipur along with their associated religious beliefs and taboos (Khumbonmayum, 2004).

\section{Meghalaya}

The sacred groves in Meghalaya are known as Law Lyngdoh, Law Niam' and Law kyntang' depending on the places where they are located. A total of 101 sacred groves have been documented so far in Meghalaya. Ryngkew, Basa, labasa are some of the deities to whom these groves are dedicated. The commonly found plant species are bamboo, needle wood, Indian birch, white pear, royal robe, balsum of peru, phurse champ, lac tree and plot's elm. A number of perennial streams originate from 58 of these groves. These groves are considered as one of the most biodiversity rich areas. Ancestral worship is traditionally performed in the sacred groves. In forested areas, the focus of worship is on ancient monoliths (Tiwari et.al., 1999).

\section{Mizoram}

For the Mizos, the sacredness of the plants is the reflection of the unity of life in nature and generates a sense of communion with the divine as the centre and source of life. These sacred groves vary in size from a few hectares to few hundred hectares and are an invaluable repository of genetic diversity. Each Mizo village has its own sacred groves known as Ngawpui. They also have bamboo reserves called mawmund in Sialkal region of northeastern Mizoram (Malhotra, 1990; Gokhale et al., 1998). The sacred groves are a natural habitat of streams, rocks, hills, plants and trees. The sacredness of the trees is an important facet of the religious, cultural and economic life of the Mizo people. They have preserved the valuable genetic resources and species which have provided a base for re-afforestation programmes.

Mizo tribals have safety reserves and supply reserves around the villages. These safety forests are a continuation of the sacred groves of the pre-Christian period (Joshi and Gadgil, 1991). However, the conversion of the Mizos to Christianity has had an adverse impact on the sacred groves since many of them have been felled to make room for the construction of churches. Having said that, it must also be admitted that even after their conversion to Christianity, the Mizo tribes have continue to respect the ancient cultural practices and taboos in connection with the sacred groves.

\section{Odisha}

The institution of sacred groves in the state is recognized by various names such as Jahera, Thakurnama, etc. Around 169 sacred groves have been reported from Odisha. Jhakeri, Gram Siri, Gossa Pennu, Pitabaldi, Loha Penu, Gaisri and Pat Baram are some of the deities to whom these groves are dedicated. The commonly found plant species are sal, mango, dumri, senha, arabian jasmine, bengal quince, billy goat-weed, axile wood, neem, pig weed and silk cotton tree etc. The unique biodiversity character has been reflected by harbouring many medicinal plants, roots, fruit trees and creepers (like siari), shrubs along with many faunal types including various resident birds, reptiles and wild animals (Malhotra et al., 2011). 


\section{Puducherry}

The sacred groves in Puducherry are locally known as 'Kovil Kadugal' and 'Ayyappan Kavu'. Around 123 patches of sacred groves varying in size from 0.2 to 5.0 ha around the temples have been identified in the Union Territory of Puducherry. Aiyanar, Pachaivazhiamman, Poraiyathamman, Pachai-vazhiamman, Celliamman, Kaliamman and Maduraiveeran are some of the deities to whom these groves are dedicated. The commonly found plant species are lebbek tree, Indian atalantia, neem, caper bush, bush plum, Indian-laburnum, Indian black plum and jackal coffees. These sacred groves are often dedicated to local spirits or deities and as such the people attach sanctity to them. Religious practices and cultural traditions have been spun around them to deter people from exploiting the biodiversity contained within them (Ramujam et al., 2007).

\section{Punjab}

In Punjab, Chatpat Nath Ji and Chatpat Bani are the deities to whom the sacred groves are dedicated. Sacred groves in Punjab have species of native trees along with thick under storey vegetation comprising of several medicinal plants, herbs and grasses (Jerath, 2014).

\section{Rajasthan}

Sacred groves are found all over Rajasthan and are called by various names such as Vani in Mewar, Kenkri in Ajmer, Oran in Jodhpur, Bikaner and Jaisalmer, Shamlat deh and Devbani in Alwar. A total of 560 sacred groves have been documented so far in Rajasthan. Garvaji, Bharthariji, Naraini Mata, Peerbaba, Hanumanji and Naharsakti Mata are the deities to whom these groves are dedicated. The commonly found plant species are Cutch tree, Indian mesquite, mukul myrrh tree, salvia leaved cross berry, Indian tree of heaven, neem, Indian plum, banyan and pipal. The tradition in Rajasthan is an ideal example of support of the tradition for ecosystem services. The resources in the groves are used in a controlled fashion or only in case of emergency. The Gurjar people of Rajasthan have a unique practice of neem (Azadirachta indica) planting and worshipping it as the abode of God Devnarayan (Aman Singh, 2014).

\section{Sikkim}

Sacred groves in Sikkim are attached to Buddhist monasteries. They are called Gumpa Forest Areas (GFA) and are managed by Lamas. A total of 56 sacred groves spread over 4 districts have been documented. Cho Chuba, Loki Sharia, Guru Padmasambhava and Rolu Devi Than are the deities to whom these groves are dedicated. The commonly found plant species are Cupressus, silver oak, tooni, thotnay, aiselu, tusare, like sanu khari and ruk saro. The highlands of Demojong below the Khangchendzonga peak are the most sacred site for the Sikkimese Buddhists. Any human activity here is believed to spell disaster for the region (The Forest, Environment \& Wildlife Management Department, Government of Sikkim, 2011).

\section{Tamil Nadu}

In Tamil Nadu, almost every village has a sacred grove. These groves range in size from 1 acre to 500 acres. The sacred groves in Tamil Nadu are known as Koil Kadu, Swami Thopu or Swami Sholai. The deities associated with the groves are Aiyanar, Sastha, Muneeswaran Karuppuswami, Vedappar, Andavar and Amman. A total of 1261 groves have been reported in Tamil Nadu. The groves are the repositories of medicinal plants. Commonly found species in the plain groves are species such as crab's eye, white babool, Siris, white cutch tree, Indian persimmon and ebony; in the coastal groves are the wild lime, iron wood tree, alangium, capper bush, indigo wodier; in the groves of the Eastern Ghats: Indian mesquite, east Indian walnut, poison nut, tamarind, ebony, persimmon; and in the groves of the Western Ghats: kurinji, white marudah, cycas, rudraksha, Indian black plum, champak and rosewood.

Once a year, a festival is held in the grove. Pongal is prepared for which dry twigs from the grove are used. Apart from this, twigs and branches of the groves cannot be plucked or made use of. It is mandatory that the grove is always kept clean; one is not allowed to urinate or defecate within the grove. The characteristic feature of sacred groves in Tamil Nadu is the offering of terracotta figures. Terracotta plays a major role, representing the powers of renewal inherent in the earth, and all the deities and votive offerings are made of clay. People make offerings of terracotta horses to Ayyanaar, the village kaaval kaaran (watchman) at the shrine of the mother Goddess. The horses are offered to him to go around the village in order to guard it (Amirthalingam, 2012).

\section{Uttarakhand}

The sacred groves in Uttarakhand are locally known as Deo Bhumi and Bugyal (sacred alpine meadows). A total of 126 sacred groves have been documented so far. 
Chandrabadni Devi, Hariyali Devi, Kotgadi Ki Kokila Mata, Pravasi Pavasu Devata, Devrada and Saimyar are the deities to whom these groves are dedicated. The commonly found plant species are turnip-root chervil, Himalayan cedar, Sanjeevani, Indian barberry, Himalayan firethorn and Indian valerian. The unique features of sacred groves include the sacred Natural Site (SNS), Management system, the taboo system, festivals, dominant vegetation and service provided by the groves.

Sacred Natural Sites (SNS) can be defined as natural areas that carry a spiritual significance for indigenous peoples and communities. They are revered as places of worship and remembrance. Entering these sites is usually governed by the membership of a particular community that guards and protects these sites. These sites have managed to withstand the onslaught of modernization and encroachment and have largely been preserved in their original state for a period of hundreds of years. It should also not be forgotten that these natural areas have played a vital role in preserving ethnic identities and ensuring the continuity of traditional beliefs and customs (Singh et al., 2014).

\section{Uttar Pradesh}

Sacred groves are locally known as Dev Van and Van in Uttar Pradesh. So far 32 traditional sacred groves have been identified in the forest areas. Samay Than, Vansatti Devi, Bhairav Baba, Phoomati Mata, Shiva, and Ram Janaki are the deities to whom these groves are dedicated. The commonly found plant species are neem, golden shower tree, bird lime tree, East Indian rosewood, banyan, cluster fig, pipal, Indian elm, Ceylon ironwood and India jalap. The sacred groves of Uttar Pradesh hold special significance in improving the soil fertility through biomass build-up, efficient nutrient cycling, conserving soil moisture and providing a deeply penetrating root system with soil-binding properties (Singh, 2011).

\section{West Bengal}

In West Bengal sacred groves are known as Gramthan, Haritan Sabitritan, Jahera, Deo Tasara and Mawmund. A total of 505 sacred groves have been reported so far in West Bengal. Sitala, Garam, Manasa, Devimani (lady of the grove) and Makali are the deities to whom these groves are dedicated. The commonly found plant species are sal tree, bamboo, mango, Indian butter tree, neem, white mardah, wild date palm, narrow-leaved Indian mulberry and trumpet flower tree.
The institution of sacred groves is associated with a range of oral narratives and belief systems. Most of these groves are very small, generally less than an acre. No biomass is harvested from them. Bamboo groves are found in Jalpaiguri and Cooch Behar districts. These make up a unique social means to prevent intra-group conflicts and violation of the traditional ethos by infringements by outsiders. The sacred grove represents the unique fragments of the respective species gene pool (Deb, 2008).

\section{Conclusions}

The sacred groves can be justly described as the "lungs" of the country. The sacred groves are inextricably linked with the cultural and economic life of the local communities. The age old cultural and religious traditions of various groups of people have helped to preserve and protect these hotspots of biodiversity and ensure that they do not fall prey to the insatiable demands of industrialization, urbanization and the need to create infrastructure. The sacred groves, on their part, have fulfilled their role by sustaining the economic, medicinal and religious needs of the local communities who depend upon them. They abound in rich biodiversity and are home to various rare and endangered plant and animal species that have great medicinal value. These green oases of trees, shrubs, herbs and climbers play a vital role in maintaining the ecosystem and ecological balance.

Many species that have become extinct in other parts of the country are well preserved in these groves. These areas also provide natural habitat, water, and nesting sites for many species of wildlife and birds. They also act as a gene bank of various plants and animals, thus ensuring that these species do not become extinct. In short, one may conclude that these groves are a vital part of the life support system of our planet, since they ensure that we get clean air to breathe, wholesome food and medicinal supplies and clean water to drink not only for human beings but also for the innumerable species that abound on this earth.

\section{Conflict of interest statement}

Authors declare that they have no conflict of interest.

\section{Acknowledgement}

I wish to express my gratitude to Dr. Nanditha Krishna, Honorary Director of C.P.R. Environmental Education 
Centre for her constant encouragement which led me to deepen my interest in the study of the sacred groves of India.

\section{References}

Amairthalingam, M., 2012. Sacred Groves of Tamil Nadu and their Management. Forest Department, Government of Tamil Nadu, Chennai.

Aman Singh, 2014. Sacred groves of Rajasthan. In: Sacred Groves of India - A Compendium (Eds.: Nanditha Krishna, Amirthalingam, M.). C.P.R. Environmental Education Centre, Chennai. pp.359-365,

Chandran, M.D.S., Ramachandra, T.V., 2014. Salvaging sacred groves -The imperiled museums of Indian culture and biodiversity. In: Sacred Groves of India - A Compendium (Eds.: Nanditha Krishna, Amirthalingam, M.). C.P.R. Environmental Education Centre, Chennai. pp.175-186.

Deb, D., 2008. Joint forest management. In: Status of Environment in West Bengal: A Citizens' Report (Ed.: Ghosh, A.K.). ENDEV Society for Environment and Development, Kolkata. pp.96-104.

Deshmukh, S., 1999. Conservation and Development of Sacred Groves in Maharashtra - Final Report of the world Bank Aided Maharashtra Forestry Project, BNHS, Mumbai. 289p.

Ghate, V., 2014. Maharashtra: Unique plant diversity of sacred groves. In: Sacred Groves of India - A Compendium (Eds.: Nanditha Krishna, Amirthalingam, M.). C.P.R. Environmental Education Centre, Chennai. pp.283-293.

Gokhale, Y., Velankar, R., Subash Chandran, M.D., Gadgil, M., 1998. Sacred woods, grasslands and water bodies as self-organized systems of conservation. In: Conserving the Sacred for Biodiversity Management (Eds.: Ramakrishnan, P.S., Saxena, K.G., Chandrashekara, U.M.) Oxford and IBH Publishing Co., New Delhi, pp.365-398.

Induchoodan, N.C., 1996. Ecological Studies of the Sacred Groves of Kerala. Ph.D. Thesis, Central University of Pondicherry, India.

Jerath, N., 2014. Socio-Cultural and Religious Practices in Biodiversity Conservation in Punjab. In: Ecological Traditions of India, Vol. VIII, Punjab (Ed.: Nanditha Krishna). C.P.R.Environmental Education Centre, Chennai and ENVIS Centre - www. Cpreecenvis.nic.in. pp.9-24.

Joshi, N.V., Gadgil, M., 1991. On the role of refugia in promoting prudent use of biological resources. Theor. Popul. Biol. 40, 211-229.

Kerkar, R., 2010. Ecological Traditions of Goa. C.P.R. Environmental Education Centre Chennai. pp.77-94.

Khan, M. L., Khumbongmayum, A.D., Tripathi, R. S., 2008. The sacred groves and their significance in conserving biodiversity-an overview. Int. J. Ecol. Environ. Sci. 34(3), 277-291.
Khumbongmayum, A.D., Khan, M. L., Tripathi, R. S., 2004. Sacred groves of Manipur - ideal centres for biodiversity conservation. Curr. Sci. 87(4), 430-433.

Kushalappa, C.G., 2014. Devarakaadu - Sacred forests of Kodagu District, Karnataka. In: (Eds.: Nanditha Krishna, Amirthalingam, M.). C.P.R. Environmental Education Centre, Chennai. pp.167-174.

Mahato, A.K.R., 2014. Jharkhand: Cultures of the indigenous communities of Chhotanagpur Plateau - their role in biodiversity conservation. In: (Eds.: Nanditha Krishna, Amirthalingam, M.). C.P.R. Environmental Education Centre, Chennai. pp.163-166.

Malhotra, K .C., Shashi Stanley, Hemam, N.S., Ketaki Das, 2011. Biodiversity Conservation and ethics: Sacred groves and pools. In: Ecological Traditions of India, Vol. VII, Odisha (Ed.: Nanditha Krishna). C.P.R.Environmental Education Centre, Chennai and ENVIS Centre www.cpreecenvis.nic.in. pp.77-87.

Malhotra, K. C., 1990. Supply and Safety forests in Mizoram. Abstract, Vth International Conference on Ecological Sciences, 439, Yokohama.

Malhotra, K.C., 1998. Anthropological dimensions of sacred groves in India: An overview. In: Conserving the Sacred for Biodiversity Management (Eds.: Ramakrishnan, P.S., Saxena, K.G., Chandrashekara, U.M.) Oxford and IBH Publishing Co., New Delhi. pp.423-438.

Medhi, P., Borthakur, S.K., 2014. Sacred groves and sacred plants of the Dimasas of North Cachar Hills of Northeast India. Afr. J. Plant Sci. 7(2), 67-77.

Mishra, A., 2005. A draft Report Biodiversity and Action Plan for Bihar. Kalpavriksh, Pune. pp.169-170.

Mitra, A., Pal, S., 1994. The spirit of the sanctuary. Down to Earth, January 31.

Patel, H. R., Patel, R.S., 2012. Study of sacred groves and sacred plants of R.D.F. Poshina forest range of Sabarkantha District, North Gujarat, India. Life Sci. Leaflet. 5, 11-16.

Patel, P. K., 2004. Floristic study on Saraswati River from Mukteshwar to Patan District with Ethnobotanical aspects. Ph.D. Thesis, H.N.G. University, Patan.

Patnaik, S., Pandey, A., 1998. A study of indigenous community based forest management system: Sarna (Sacred Grove). In: Conserving the Sacred for Biodiversity Management (Eds.: Ramakrishnan, P.S., Saxena, K.G., Chandrashekara, U.M.) Oxford and IBH Publishing Co., New Delhi. pp.315-321.

Rai, R., 2014. Sacred groves in tribal pockets of Madhya Pradesh and plants conserved by ethnic communities in conservation of biodiversity. In: Ecological Traditions of Madhya Pradesh, Vol. IX (Ed.: Nanditha Krishna). C.P.R. Environmental Education Centre, Chennai \& ENVIS Centre - www.cpreecenvis.nic.in. pp. 80-96.

Ramanujam, M.P., Ganesan, T., Kadamban, D., Kumarvelu, G., Devaraj, P., 2007. Flora of Sacred Groves of Puducherry Region (A Pictorial Guide). Forest Department Government of Puducherry, Puducherry. 
Sharma, S., Devi, R., 2014. Sacred groves: Traditional way of conserving plant diversity in Bhalwal block of Jammu district (J\&K). Int. J. Sci. Res. 3(2). 239-242.

Singh, H., Husain, T., Priyanka, A., 2014. Haat Kali Sacred Grove, Central Himalaya, Uttarakhand. In: Sacred Groves of India - A Compendium (Eds.: Nanditha Krishna, Amirthalingam, M.). C.P.R. Environmental Education Centre, Chennai. pp.359-365.

Singh, N.K., 2011. Survey of sacred groves of Devipatan region of U.P. In: Forest Biodiversity: Earth's Living Treasure. Uttar Pradesh State Biodiversity Board, Uttar Pradesh. pp.153-157.
Tiwari, B.K., Barik, S.K., Tripathi, R.S., 1999. Sacred Forests of Meghalaya: Biological and Cultural diversity, Shillong: Regional Centre, National Afforestation and EcoDevelopment Board, North Eastern Hill University, Shillong.

WWF-Andhra Pradesh, 1996. Sacred Groves of Andhra Pradesh. World Wide Fund for Nature. Andhra Pradesh State Office, Hyderabad.

Yadav, S., Yadav, J. P., Arya, V., Panghal, M., 2010. Role of sacred groves in conservation of plant biodiversity in Mahendergarh District of Haryana. Ind. J. Trad. Knowl. 9(4), 693-700.

\section{How to cite this article:}

Amirthalingam, M., 2016. Sacred groves of India - An overview. Int. J. Curr. Res. Biosci. Plant Biol. 3(4), 64-74. doi: http://dx.doi.org/10.20546/ijcrbp.2016.304.011 